\title{
GROUNDWATER QUALITY ASSESSMENT FOR DRINKING PURPOSES USING GIS MODELLING (CASE STUDY: CITY OF TABRIZ)
}

\author{
M. Jeihouni ${ }^{\text {a, } *}$, A. Toomanian ${ }^{\text {a }}$, M. Shahabi ${ }^{\text {b }}$, S. K. Alavipanah ${ }^{\text {a }}$
${ }^{a}$ Dept. of Remote Sensing and GIS, Faculty of Geography, University of Tehran, Azin Str. 50, Vesal Str., Tehran, Iran, ( jeihouni92, a.toomanian, salavipa)@ut.ac.ir
${ }^{\mathrm{b}}$ Dept. of Soil Science, Faculty of agriculture, University of Tabriz, 29 Bahman Blvd, Tabriz, Iran, m.shahabi@tabrizu.ac.ir

KEY WORDS: Analytic Hierarchy Process, Groundwater quality, Drinking water, GIS, Geostatistics

\begin{abstract}
:
Tabriz is the largest industrial city in North West of Iran and it is developing rapidly. A large proportion of water requirements for this city are supplied from dams. In this research, groundwater quality assessed through sampling 70 wells in Tabriz and its rural areas. The purposes of this study are: (1) specifying spatial distribution of groundwater quality parameters such as Chloride, Electrical Conductivity (EC), pH, hardness and sulphate (2) mapping groundwater quality for drinking purpose by employing Analytic Hierarchy Process (AHP) method in the study area using GIS and Geosatistics. We utilized an interpolation technique of ordinary kriging for generating thematic map of each parameter. The final map indicates that the groundwater quality increase from North to South and from West to East of the study area. The areas located in Center, South and South West of the study area have the optimum quality for drinking purposes which are the best locations to drill wells for supplying water demands of Tabriz city. In critical conditions, the groundwater quality map as a result of this research can be taken into account by East Azerbaijan Regional Water Company as decision support system to drill new wells or selecting existing wells to supply drinking water to Tabriz city.
\end{abstract}

\section{INTRODUCTION}

Groundwater is an important source of drinking water for many people around the world (Nas and Berktay, 2010). In addition, in arid and semi-arid regions, it is the most important source of water supply (Sener and Davraz, 2013). Tabriz city is located in semi-arid region and population growth in recent years faces the city with water supply challenges. So a major issue is to find optimum locations for high quality groundwater for drinking purpose to supply water demands.

Many studies have been carried out that Geographic Information Systems (GIS) is a powerful tool to assess the water quality. Natural resources and environmental concerns, including groundwater, have benefited greatly from the use of GIS (Engel and Navulur, 1999). Hudak and Sanmanee (2003) applied GIS to assess the spatial patterns of nitrate, chloride, sulphate, and fluorides concentrations in the Woodbin aquifer of north-central Texas. Some similar studies about groundwater hardness and chemical quality using GIS have been carried out by (Hudak, 2000, 2001) in USA. Nas and Berktay (2010) used GIS and Geostatistics to survey groundwater quality map in central part of Turkey.

Geostatistics is a useful technique to handle spatially distributed data such as soil, groundwater pollution, Mining, Geology, Hydrology, Meteorology and Environmental Sciences (Arsalan, 2012), (Delgado et al., 2010), (Gokalp et al., 2010), (Nas and Berktay, 2010) and (Cemek et al., 2007). Geostatistics identifies spatial patterns and interpolates values at unsampled locations, where plays a crucial role in the sustainable management of groundwater systems (Kumar, 2007).
Yimit et al. (2011) utilized kriging method, a geostatistical technique, to assess the groundwater quality. They analysed spatial and temporal variations of groundwater levels and salinity in the Ili River Irrigation Area in the western arid zone of China. For more details and explanation on the kriging technique and its applications in groundwater or related problems, refer to works of (Mcgrath and Zhang, 2003), (Gaus et al., 2003), (Stein, 1999) and (Yamamoto, 2000). Nas and Berktay (2010) produced water quality map by overlapping thematic maps as a result of geostatistical analysis. Yet, all thematic layers have the same weights which is not the case in all factors. So Multi-criteria Decision Making (MCDM) technique is suitable to overcome such problems.

Analytic Hierarchy Process (AHP) developed by Saaty (1980), has been used in numerous applications in natural resources, environmental planning and management. Kolat et al. (2006) recommended AHP method to prepare geotechnical microzonation map in central Turkey. Chowdhury et al. (2009) employed AHP to identify the groundwater potential zones in India. AHP is also used to evaluate the groundwater potential in India (Jha et al., 2010). Do et al. (2013) employed AHP method to calculate river water quality sampling frequency. Kaya and Kahraman (2011) employed AHP method to analyse environmental impact assessments. Finally, Sener and Davraz, (2013) employed AHP method to assess the groundwater vulnerability in Turkey.

The present study's purposes are as follows: (1) to specify spatial distribution of groundwater quality parameters such as

* Corresponding author. 
Chloride, electrical conductivity, $\mathrm{pH}$, hardness and sulphate (2) to map groundwater quality for drinking purpose by employing AHP method in the study area using GIS and Geosatistics.

\section{METHODS AND MATERIALS}

\subsection{Study area}

Tabriz city is the capital of the East Azerbaijan province, located in North-western Iran, and lies between Latitude $37^{\circ}$ $57^{\prime}$ to $38^{\circ} 10^{\prime} \mathrm{N}$ and Longitude $46^{\circ} 5^{\prime}$ to $46^{\circ} 33^{\prime} \mathrm{E}$ (Fig.1). The population is 1494998 in last census report in 2011. The average annual precipitation is $290 \mathrm{~mm}$ and the climate is semiarid. A large proportion of water requirements are supplied from two dams (Norozlou and Nahand).

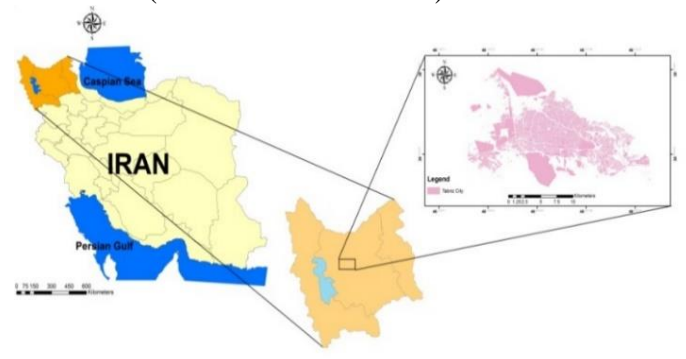

Fig1. Study Area location

The major cities in East Azerbaijan, especially Tabriz, are currently in a critical situation due to the population growth and growing demand for water and therefore limited water supply. The data of 70 wells have been used in this study (Fig.2). Data set was collected by the Iranian Ministry of Energy (IMOE).

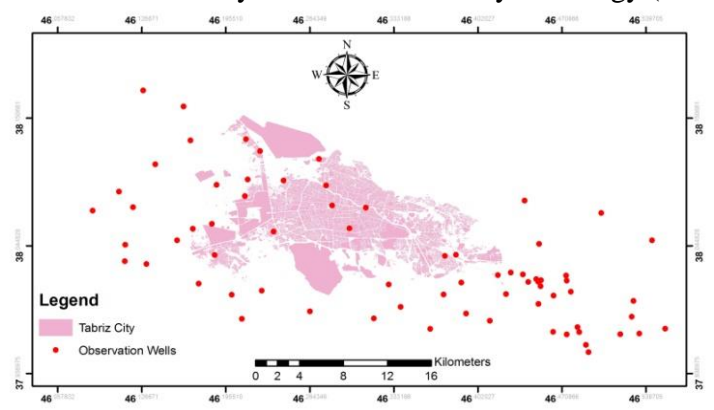

Fig 2. Observation wells location

\subsection{Geostatistics}

Geostatistics is a branch of statistics focusing on spatial or spatiotemporal datasets. The theoretical basis of geostatistics has been utterly described by several authors (Isaaks and Srivastava, 1989), (Xie et al., 2011) and (Mendes and Ribeiro, 2010). The main tool in geostatistics is the variogram, which expresses the spatial dependence between neighbouring observations (Isaaks and Srivastava, 1989). The variogram can be defined as one-half the variance of the difference between the attribute values at all points separated by $h$ as follows (1):

$$
\gamma(h)=\frac{1}{2 N(h)} \sum_{i=1}^{N(h)}\left[Z\left(x_{i}\right)-Z\left(x_{i}+h\right)\right]^{2}
$$

Where $\mathrm{N}$ represents the number of pairs of observations separated by the distance $\mathrm{h}$ where $\mathrm{Z}(\mathrm{xi})$ is the water quality value at point $\mathrm{i}, \mathrm{Z}(\mathrm{xi}+\mathrm{h})$ is the water quality value of other points separated from $x i$, by a discrete distance $h$, xi are the georeferenced positions where the $\mathrm{z}(\mathrm{xi})$ values were measured and $\gamma(\mathrm{h})$ is the estimated or "experimental" semi-variance value for all pairs at a lag distance $\mathrm{h}$ (Hernández-Stefanoni and Ponce-Hernández, 2006). For specific detail on geostatistics and its applications refer to (Goovaerts et al., 2005), (Gringarten and Deutsch, 2001) and (Isaaks and Srivastava, 1989).

\subsection{AHP}

AHP is one of the most commonly applied MCDM techniques in many disciplines. It was developed to solve problems that involve prioritization of potential alternative solutions (Byun, 2001). The method is a well-known tool for decision making in operational analysis (Solnes, 2003). AHP is used in situations where the hierarchy of decisions components is used for decision-making. As mentioned in the literature, we assign weights to components as stated in Saaty's scale (Table1).

\begin{tabular}{|c|c|}
\hline Weight & Intensities \\
\hline 1 & Equal \\
3 & Moderately \\
5 & Strongly dominant \\
7 & Very Strongly dominant \\
9 & Extremely dominant \\
$2,4,6,8$ & Intermediate Values \\
\hline
\end{tabular}

Table1. AHP paired comparison judgments from a fundamental scale of absolute numbers for assigning weight values (Saaty Scale) (Saaty, 2006)

According to AHP method saaty (1980), water quality analyst experts were interviewed to ask them the relative importance of the water quality variables (parameters) on drinking purpose. The experts assigned weights for the selected thematic maps and its features on Saaty's scale (Table1). The weights calculated for each thematic map were the results of a pair wise comparison of each parameter based on their relative importance to groundwater quality. The weights assigned to different thematic maps were normalized by AHP, which represent the importance of these thematic layers in groundwater quality. The normalization process reduces the scale associated with the weights that assigned to the variables (thematic maps) and their features.

In this study, first the histograms of each parameter has been checked to see if it shows a normal distribution pattern then we used 70 sampling points to develop interpolation map of spatial distribution of each water quality parameter by employing ordinary kriging over the study area. Trend analysis was made and the 11 different semivariogram models were tested for each parameter. Finally, performances were assessed by crossvalidation and the final AHP quality map produced by the weight that experts assigned to each parameter.

\section{RESULT AND DISCUSSION}

Groundwater quality indicates the water usability for different purposes. The standard quality for drinking water has been specified by the World Health Organization (WHO) (World Health Organization, 2011). It has given the acceptable limits for the presence of various elements in groundwater. 


\begin{tabular}{|l|l|l|l|l|l|l|l|l|}
\hline Parameter & Min & Max & Mean & Median & SD & Skewness & Kurtosis & Transformation \\
\hline $\mathrm{pH}$ & 7 & 8.7 & 8.01 & 8 & 0.39 & 0.4 & 3.02 & Lognormal \\
$\mathrm{EC}(\mu \mathrm{S} / \mathrm{cm})$ & 208 & 12555 & 19058 & 929.25 & 2219.2 & 2.49 & 10.46 & Lognormal \\
Chloride $(\mathrm{mg} / \mathrm{L})$ & 0.225 & 79.5 & 10.62 & 2.65 & 16.19 & 2.14 & 7.68 & Lognormal \\
Sulphate $(\mathrm{mg} / \mathrm{L})$ & 0.175 & 17.95 & 4.29 & 3 & 3.68 & 1.25 & 4.42 & Lognormal \\
Hardness & 4.177 & 110.7 & 29.29 & 19.23 & 24.20 & 1.26 & 3.95 & Lognormal \\
\hline
\end{tabular}

Table2. Statistical evaluation of groundwater quality parameters

Statistical evaluation of groundwater quality parameters showed in Table 2. The data was not in the form of normal distribution, but Kriging methods had the best results when the data are approximately normally distributed. So for all parameters we transform to normal distribution by applying lognormal transformation.

In this study, we tested 11 semivariogram models (Circular, Spherical, Tetraspherical, Pentaspherical, Exponential, Gaussian, Rational Quadratic, Hole effect, K-Bessel, J-Bessel, Stable) for each parameter. As an example, Fig. 3 shows the Circular semivariogram and semivariogram surface that fitted to EC dataset. The summary of semivariogram model parameters for each water quality factor showed in Table 3 . As indicated in Table 3, the $\mathrm{pH}$ has the minimum range that shows its high spatial variability.

The prediction performances were assessed by cross-validation. We used Cross-validation that allows to determination of which model provides the best predictions, (Results in Table 4).

The spatial distribution of $\mathrm{pH}$, Electrical conductivity, chloride, sulphate and hardness distribution is showed in Fig. 4. The related thematic maps were generated according to the classification implied by Ducci (1999), shown in Table 5 .

The final groundwater quality map was generated by employing AHP method, by using thematic maps produced as a result of kriging interpolations (Fig.5).
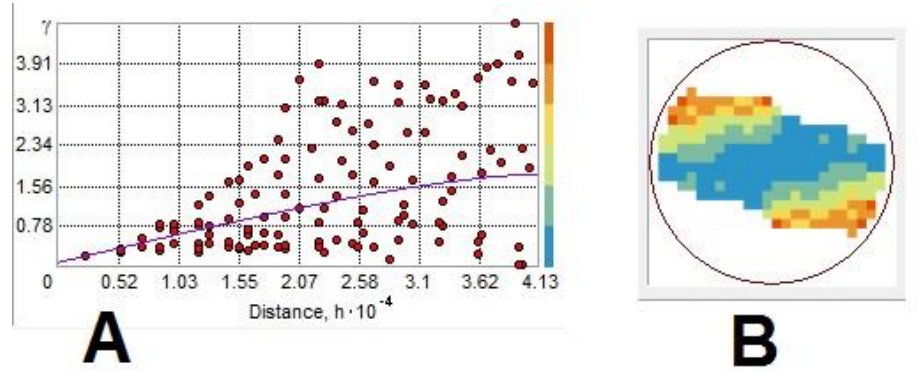

Fig.3 A) Semivariogram, B) Semivariogram Surface that related to EC dataset.

\begin{tabular}{|l|l|l|l|l|}
\hline Parameter & Models & Nugget & Sill & Range $(\mathrm{m})$ \\
\hline $\mathrm{pH}$ & Spherical & 0 & 0.0033 & 891.7740 \\
EC & Hole Effect & 0.1879 & 1.0907 & 40825 \\
Chloride & Hole Effect & 0.3783 & 2.9126 & 40825 \\
Sulphate & Rational Quadratic & 0.4031 & 0.9953 & 40825 \\
Hardness & Spherical & 0.0676 & 1.0856 & 40825 \\
\hline
\end{tabular}

Table 3. Semivariogram model parameters for ground water quality factors

\begin{tabular}{|l|l|l|l|l|}
\hline Parameter & Models & Root-mean square & Mean & $\begin{array}{l}\text { Root-mean-square } \\
\text { standardized }\end{array}$ \\
\hline $\mathrm{pH}$ & Spherical & 0.4 & 0.02 & 0.88 \\
$\mathrm{EC}$ & Hole Effect & 1473 & 1.48 & 0.61 \\
Chloride & Hole Effect & 11.44 & 0.07 & 1.2 \\
Sulphate & Rational Quadratic & 2.44 & 0.01 & 1.1 \\
Hardness & Spherical & 17.29 & 0.13 & 0.53 \\
\hline
\end{tabular}

Table 4. Cross-validation results for water quality factors

\begin{tabular}{|c|c|c|c|c|c|}
\hline Quality & Class & $\mathrm{EC} \mu \mathrm{S} / \mathrm{cm}$ & $\begin{array}{c}\text { Chloride } \\
(\mathrm{mg} / \mathrm{L})\end{array}$ & $\begin{array}{c}\text { Sulphate } \\
(\mathrm{mg} / \mathrm{L})\end{array}$ & Hardness \\
\hline Optimum & $\mathrm{A}$ & $<1000$ & $<50$ & $<50$ & $<30$ \\
Medium & $\mathrm{B}$ & $1000-2000$ & $50--200$ & $50-250$ & $30-50$ \\
Poor & $\mathrm{C}$ & $>2000$ & $>200$ & $>250$ & $>50$ \\
\hline
\end{tabular}

Table 5. Groundwater quality classification (Ducci, 1999) 


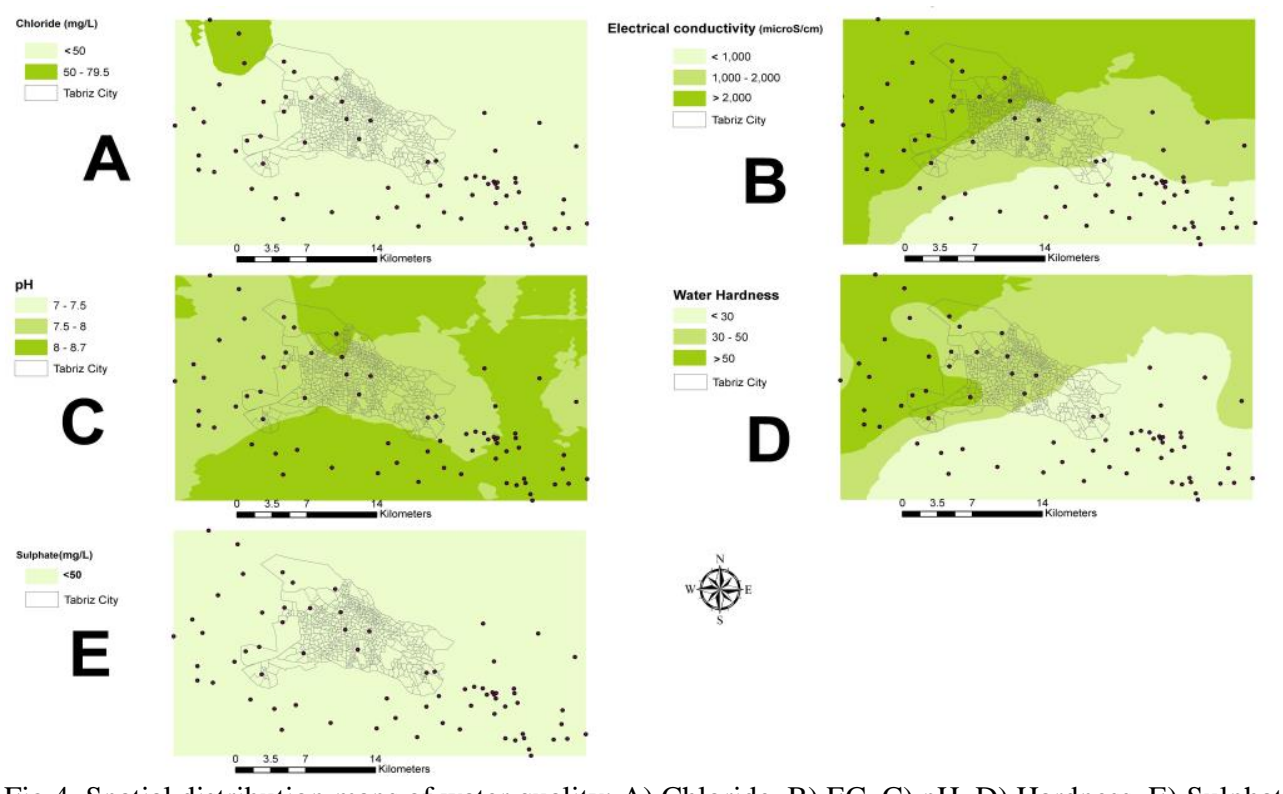

Fig.4. Spatial distribution maps of water quality; A) Chloride, B) EC, C) pH, D) Hardness, E) Sulphate

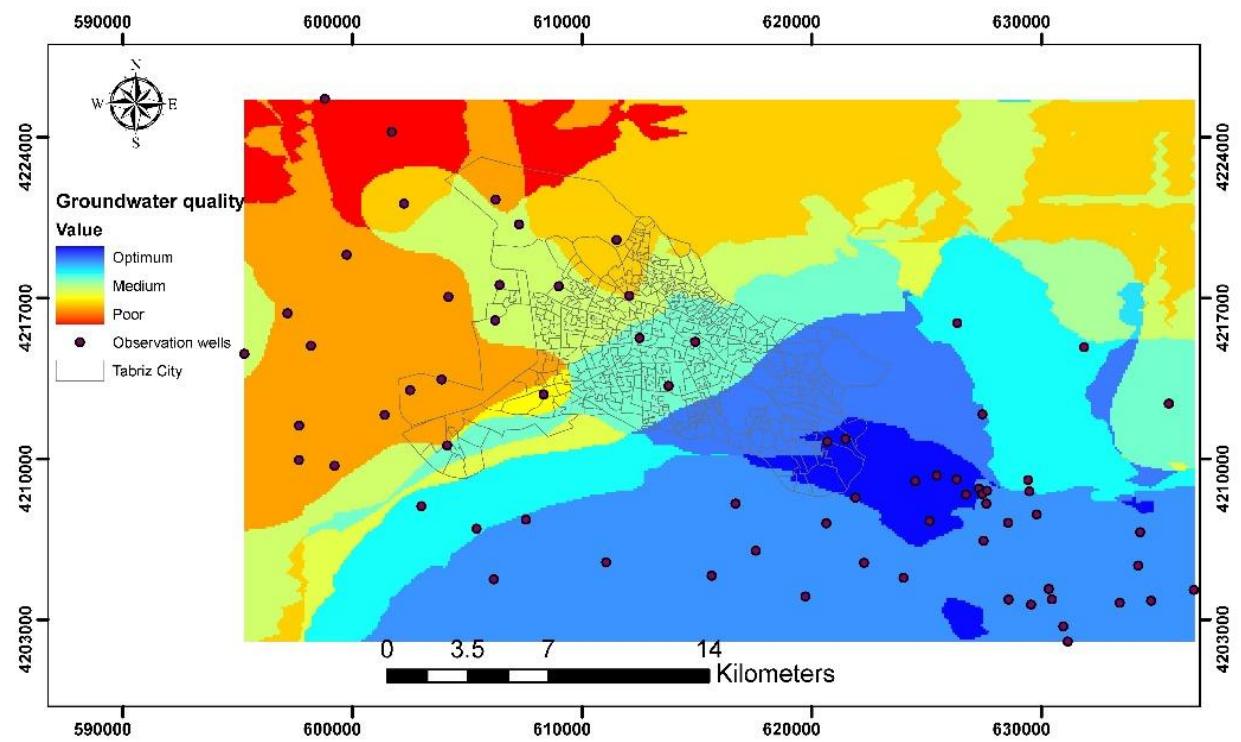

Fig 5. Water quality map using AHP method (optimum in blue and poor in red)

\begin{tabular}{|l|l|}
\hline \multicolumn{1}{|c|}{ Parameter } & \multicolumn{1}{c|}{ Description } \\
\hline EC & $\begin{array}{l}\text { In EC distribution map indicate that EC is decrease from } \\
\text { North to South and it because of Sahand Mountain located } \\
\text { in south-East of Tabriz city which covered by snow must of } \\
\text { year and this snow recharges the groundwater, because of that } \\
\text { the wells which located in south and south-East of Tabriz city } \\
\text { has minimum EC than other areas }\end{array}$ \\
\hline Sulphate & $\begin{array}{l}\text { There isn't any problem about sulphate because its } \\
\text { concentration is low in this area. }\end{array}$ \\
\hline Chloride & $\begin{array}{l}\text { There isn't any problem of chloride in the study area except } \\
\text { small area in north west of the study area that is not high } \\
\text { amount. }\end{array}$ \\
\hline pH & $\begin{array}{l}\text { There is a various range of pH in the study area maximum pH } \\
\text { have seen is 8.7 which is a little bit more than WHO standard } \\
\text { and its maybe because of areas lithology. }\end{array}$ \\
\hline Hardness & $\begin{array}{l}\text { Decrease from North to south and from West to East and its } \\
\text { because of Sahand Mountain and recharching role and its may } \\
\text { be because of Sahand Mountain areas lithology. }\end{array}$ \\
\hline
\end{tabular}

Table 6 . The spatial distribution and evaluation of water quality parameters 
According to Fig.4 and Table 6, there isn't any problem of chloride and sulphate for drinking purpose standards (World Health Organization, 2011). The distribution of EC and Hardness are similar and both decrease from North to South and from West to East of the study area due to Sahand Mountain recharging role. This rarifies the density of anions and cations in groundwater and increase its quality. As illustrated in Fig.4, the groundwater $\mathrm{pH}$ increases from West to East of the study area. This might be due to industrial sites that are located in West of the study area which produce acidic sewage and release them into surface waters. Finally, sewage permeates to groundwater and decrease groundwater $\mathrm{pH}$.

Fig. 5 shows the final groundwater quality map generated by employing AHP method and assigning priorities weight by interviewing experts. The optimum groundwater quality sites are located in large areas at the East of Tabriz city, also South, South East of the study area. As indicated in Fig.5, 8 wells exist in optimum area and 37 wells exist in areas having optimum and near optimum water quality. Finally, wells which located in East, South East and South have optimum quality because of Sahand Mountain and its recharging role in groundwater resources.

According to Fig. 5, the optimum groundwater quality sites are located in the underground of the city which causes some specific circumstances. The advantage of such situation is cost reduction of transferring and pipeline construction and the disadvantage is that the groundwater is vulnerable to be polluted by contaminants, sewage, urban runoff and industrial wastewaters.

\section{CONCLUSION}

The main goal of this study was to map and evaluate the groundwater quality of Tabriz city. Spatial distribution of groundwater quality parameters $(\mathrm{EC}, \mathrm{pH}$, chloride, sulphate and hardness) were produced by employing GIS and geostatistical techniques. Thematic maps of parameters distribution produced by using geostatistics technique. Geostatistics method has an uncertainty and the prediction surfaces were evaluated by cross validation. As we used AHP method by assigning priorities weight for each parameter this method provides reliable results for decision making. The final map, produced by employing AHP method, shows East, South East and South of study area have optimum groundwater quality. In general, the groundwater quality increases from North to South and from West to East and this is because of its closeness to Sahand Mountain and its recharging role on groundwater. In critical conditions, the groundwater quality map as a result of this research can be taken into account by East Azerbaijan Regional Water Company as decision support system to drill new wells or selecting existing wells to supply drinking water to Tabriz city.

\section{REFERENCES}

Arslan, H., 2012. Spatial and temporal mapping of groundwater salinity using ordinary kriging and indicator kriging: The case of Bafra Plain, Turkey. Agricultural Water Management,113, pp. $57-63$.

Byun, D. H., 2001. The AHP approach for selecting an automobile purchase model. Information \& Management, 38, pp. 289-297.
Cemek, B., Güler, M., K1lıc, K., Demir, Y., \& Arslan, H., 2007. Assessment of spatial variability in some soil properties as related to soil salinity and alkalinity in Bafra plain in northern Turkey. Environmental Monitoring and Assessment, 124, pp. 223-234.

Chowdhury, A., Jha, MK., Chowdary, VM., \& Mal, BC., 2009. Integrated remote sensing and GIS-based approach for assessing groundwater potential in West Medinipur District, West Bengal, India. International Journal of Remote Sensing, 30(1), pp. 231250

Delgado, C., Pacheco, J., Cabrea, A., Baltlori, E., Orellana, R, \& Baustista, F., 2010. Quality of groundwater for irrigation in tropical karst environment; the case of Yucatan, Mexico. Agricultural Water Management, 97, pp. 1423-1433.

Do, H.T., Lo, S.L., \& Phan, Thi. La., 2013. Calculating of river water quality sampling frequency by the analytic hierarchy process (AHP). Environmental Monitoring and Assessment, 185(1), pp. 909-916.

Engel, B. A., \& Navulur, K. C. S., 1999. The role of geographical information systems in groundwater engineering. In J. W. Delleur (Ed.), The handbook of groundwater engineering, Boca Raton: CRC. pp. 21, 1-16.

Gaus, I., Kinniburgh, D.G., Talbot, J.C., \& Webster, R., 2003. Geostatistical analysis of arsenic concentration in groundwater in Bangladesh using disjunctive kriging. Environmental Geology, 44, pp. 939-948.

Gokalp, Z., Basaran, M., Uzun, O., \& Serin, Y., 2010. Spatial analysis of some physical soil properties in a saline and alkaline grassland soil of Kayseri, Turkey. African Journal of Agricultural Research, 5 (10), pp. 1127-1137.

Goovaerts, P., AvRuskin, G., Meliker, J., Slotnick, M., Jacquez, G., \& Nriagu, J., 2005. Geostatistical modeling of the spatial variability of arsenic in groundwater of southeast Michigan. Water Resources Research, 41(7). doi:10.1029/2004WR003705

Gringarten, E., \& Deutsch, C. V., 2001. Teacher's aide variogram interpretation and modeling. Mathematical Geology, 33(4), pp. 507-534.

Hernández-Stefanoni, J.L., \& Ponce-Hernández, R., 2006. Mapping the spatial variability of plant diversity in a tropical forest: comparison of spatial interpolation methods. Environmental Monitoring and Assessment, 117, pp. 307-334.

Hudak, P. F., 2000. Regional trends in nitrate content of Texas groundwater. Journal of Hydrology (Amsterdam), 228(1-2), pp. $37-47$. 
Hudak, P. F., 2001. Water hardness and sodium trends in Texas aquifers. EnvironmentalMonitoring and Assessment, 68, pp. $177-185$.

Hudak, P. F., \& Sanmanee, S., 2003. Spatial patterns of nitrate, chloride, sulfate, and fluoride concentrations in the woodbine aquifer of North-Central Texas. Environmental Monitoring and Assessment, 82, pp. 311- 320 .

Isaaks, E.H., \& Srivastava, R.M., 1989. An Introduction to Applied Geostatistics. Oxford Univer. Press, New York, USA.

Jha, MK., Chowdary, VM., \& Chowdhury, A., 2010. Groundwater assessment in Salboni Block, West Bengal (India) using remote sensing, geographical information system and multi-criteria decision analysis techniques. Hydrogeology, 18(7), pp. 1713-1728.

Kaya, T., \& Kahraman, C., 2011. An integrated fuzzy AHPELECTRE methodology for environmental impact assessment. Expert Systems with Applications, 38, pp. 8553-8562.

Kolat, C., Doyuran, V., Ayday, C., \& Süzen, M., 2006. Preparation of a geotecshnical micro-zonation model using geographical information systems based on multi-criteria decision analysis. Environmental Geology, 87, pp. 241-255.

Kumar, V., 2007. Optimal contour mapping of groundwater levels using universal kriging - a case study. Hydrological Sciences Journal, 52 (5), pp. 1039-1049.

Mcgrath, D., \& Zhang, C., 2003. Spatial distribution of soil organic carbon concentrations in grassland of Ireland. Applied Geochemistry, 18, pp. 1629-1639.

Nas, B., \& Berktay, A., 2010. Groundwater quality mapping in urban groundwater using GIS. EnvironmentalMonitoring and Assessment, 160, pp. 215 -227.

Saaty, TL., 1980. The Analytic Hierarchy Process: Planning, Priority Setting, Resource Allocation. McGraw-Hill: New York; 287.

Saaty, T.L., 2006. Rank from comparisons and from ratings in the analytic hierarchy/network processes. European Journal of Operational Research, 168(2), pp. 557-570.

Sener, E., \& Davraz, A., 2013. Assessment of groundwater vulnerability based on a modified DRASTIC model, GIS and an analytic hierarchy process (AHP) method: the case of Egirdir Lake basin (Isparta, Turkey). Hydrogeology Journal, 21(3), pp. $701-714$.

Solnes, J., 2003. Environmental quality indexing of large industrial development alternatives using AHP. Environmental Impact Assessment Review, 23(3), pp. 283-303.
Stein, M. L., 1999. Interpolation of spatial data: Some theory for kriging, Berlin: Springer.

WHO (World Health Organization) (2011). Guidelines for drinking water quality, fourth edition. Geneva: WHO.

Yamamoto, J. K., 2000. An alternative measure of the reliability of ordinary kriging estimates. Mathematical Geology, 32(4), pp. 489-509.

Yimit, H., Eziz, M., Mamat, M., \& Tohti, G., 2011. Variations in groundwater levels and salinity in the Ili River Irrigation Area, Xinjiang, Northwest China: a geostatistical approach. International Journal of Sustainable Development \& World Ecology, 18 (1), pp. 55-64. 